\title{
Semantic Prosody Study of 'Talking a lot' Words
}

\author{
Andiani Rezkita Nabu \\ arezkita.nabu@iaingorontalo.ac.id \\ IAIN Sultan Amai Gorontalo, Indonesia
}

\begin{abstract}
Due to sentence formation, the lexicon choice appears as a crucial phase of writing. Moreover, it is caused by the emptiness of words set that are perfectly synonymous and can be interchangeable. In order that it leads the needed for meaning, sense and evocative value identification in the choice of the lexicon. Furthermore, the main objective of this research is to examine the value (sense) of several lexicons, which means 'talking a lot' such as talkative, loquacious, chatty, gossipy, garrulous, talky, and conversational, by using cognitive-linguistic and corpus linguistic approaches. In this case, the researcher examined the lexicon values based on the distinguishing semantic features and semantic prosody of the lexicons. As a linguistic corpus study, this study involved a number of data derived from COCA (Corpus of Contemporary American English), the Oxford dictionary (online), and the Merriam-Webster dictionary (online). Hence, this study found that the distinctive features of the lexicons are the subject, the object, the type of communication, the type of information, and the causes. Therefore, the semantic prosody in translation practices applies in corpus-based approach translation. It can facilitate a translator to comprehend new words and improve the quality of translation work.
\end{abstract}

Keywords: Semantic Prosody; Translation Approach; COCA; Corpus; Collocation.

\section{A. INTRODUCTION}

Vocabulary is a part of lexicogrammar that always represents the word choice of language user, and the ability of language user to mean a word (OKeeffe et al., 2007). Furthermore, the development of languages in the world appeared by the increasingly of vocabulary diversity. This diversity eventually led to the emergence of various words that have same relation meaning or synonym. The words, in addition, can be used to explain the same meaning, but cannot be truly exchanged one another. According to Bloomfield (Potter \& Ullmann, 1963), each form of language has a constant and 
specific meaning. Then, if the forms of language are phonemically different, they also have different meanings. In order that, the hypothesis about the existence of absolute synonym will be incompatible with the general view of language. Consequently, It happens as the result of there are no synonym pairs that are perfectly same in meaning, which can be exchanged in all contexts without changing their objective meaning, taste, or evocative value (Potter \& Ullmann, 1963).

On the other hand, the lexicon choice is a very crucial part in formatting a sentence. This lexicon choice can lead to the emergence of positive or negative meanings. Moreover, the existence of near synonym words sometimes leads to the vagueness in choosing words of arranging a sentence, especially for EFL students. In addition, it will make EFL students more complicated to arrange sentences. Hence, it should lead to the needed of meaning, sense and evocative value identification in the choice of lexicon. Regarding to differentiate each near synonym words, many researchers use the idea of semantic prosody or semantic preference through the collocation to help identifying the broad meaning of words (McEnery \& Wilson, 2001; Nugroho, 2018; Partington, 2004; Prihantoro, 2015; Xiao \& McEnery, 2006). Semantic prosody or semantic preference is a relationship between word lexeme and its meaning and it usually affects to the collocation and emotional factor of the hearer (Partington, 2004; Stubbs, 2001). In order that, semantic prosody also purposes for expressing language users' attitude through words (Biber \& Reppen, 2015).

As far as the discussion about semantic prosody emerges, the corpus linguistic became a best source of data used for this problem (Liu, 2010; Nugroho, 2018; Partington, 2004). Instead of using other source of data, every words can be studied easily in corpora by concerning the words phraseological structure, words genre, words variety, and words frequency (Charles, 2011). Furthermore, the studies about differentiating near synonym had been done by many researchers. The first study is a study conducted by Liu (2010) entitled "Is it a chief, main, major, primary, or principal concern?: A corpus-based behavioral profile study of the near-synonyms". This study is intended to examine the internal semantic feature of five near synonym words namely chief, main, major, primary, and principal. This study finally affirmed the use of behavioral profile approach in corpus study. 
Prihantoro (2015) with his study entitled "Semantic prosody of words of effects in Indonesian". This study aimed to examine the semantic prosody of the meaningful entries of words mean 'effects' such as hasil, efek, konsekuensi, dampak and akibat by using corpus linguistic approach . From this research, it was found that only the word hasil has a positive prosody. Meanwhile, the word konsekuensi has a positive, and the derivation of akibat, dampak, and efek has a positive and negative prosody. However, akibat, dampak, and efek are more likely to have a negative tendency than positive tendency (Prihantoro, 2015).

In addition, another research has also been done by Yuliawati (2016) with her research entitled "Profil semantik nomina perempuan dalam korpus majalah berbahasa Sunda (Majalah Mangle, 1958 - 2013)”. This study discussed the collocation and meaning of some Sundanese words such as awewe, istri, mojang, pemajikan, and wanoja by using corpus linguistic approach. As a corpus linguistic study, this study found that the use of words has different frequencies. However, by considering the collocations, each word is always associated with certain topics (Yuliawati, 2016).

Nugroho (2018) in his study also give another example of semantic prosody study through corpus. The study entitled "A corpus linguistics investigation of two nearsynonymous words: rich and wealthy" is emerged from the English learners' confusion to some near synonym words. In order that, although rich and wealthy shared some semantic features but they cannot exchangeable in certain context (Nugroho, 2018).

Another research has been carried out by Zahradeen (2020) entitled "Componential analysis of English 'Crying' terms". This study was intended to find out the distinctive features of 'crying' terms through componential analysis. Therefore, the presence and absence of features can influence the meaning of words (Tijjani Zahradeen, 2020).

The development of semantic prosody studies also has been done by Sanguan-Boon \& Tangkiengsirsin (2019) entitled "A Semantic Prosody and Grammatical Patterns Analysis of Near-Synonym Pair Quit and Stop in the COCA". This study aimed to find out the semantic prosody and grammatical pattern of near synonym words namely quit and stop. Therefore, the study found that quit and stop had neutral semantic prosody, but they cannot be used interchangeably because they had some different grammatical patterns (Treechayawong et al., 2019). 
Hwungsookkasem \& Sompong (2019) (in Treechayawong et al., 2019) in their study entitled "A Corpus-Based Study of English Synonym: Goal, Purpose, and Aim" is another newest study about semantic prosody through near synonym words. This study focused on investigating the similarities and differences of three synonym words namely goal, purpose, and aim. The similarities and differences of the words were examined by concerning the meaning aspects, grammatical patterns, and collocations of words. In this case, the data from Corpus of Contemporary American English (COCA) were compared with lexical meaning in some dictionaries. Finally, it found that the synonym word namely goal, purpose, and aim had some shared similar grammatical patterns and collocations. However, they also had some different grammatical patterns and special collocations for each word.

Based on the description above, the study entitled semantic prosody analysis of 'talking a lot' words is different with some previous study above. Therefore, this study aimed to examine and focus on the lexicon values of words 'talking a lot', such as talkative, loquacious, chatty, gossipy, garrulous, talky, and conversational. The lexicon values will be concerned on distinguishing semantic features and semantic prosody of the lexicon. In order that, this study will give a new insight of the use of near synonym words 'talking a lot' based on the aura of the lexicon through the appropriate genre and appropriate context.

\section{B. RESEARCH METHOD}

The term of prosody in corpus linguistic studies refers to the tendency of a word towards positive or negative meaning (McEnery \& Hardie, 2011). Meanwhile, the attribute 'semantics' is usually added to the word 'prosody' for emphasizing that the prosody depends on the context of the sentence, and it is also influenced by word features and their collocation (Prihantoro, 2015). Hence, Louw (Stewart, 2009) states that semantic prosody is the aura of meaning that is consistently formed based on the collocation of words and determined by the lexicon or grammar.

In providing data, researchers used data from Corpus of Contemporary American English (COCA) (Corpus of Contemporary American-English (COCA), n.d.) and compile it with the data from The Oxford Dictionary Online (Definitions, Meanings, Synonyms, and Grammar by Oxford Dictionary on Lexico.Com, n.d.) and The 
Merriam-Webster Dictionary Online (Dictionary by Merriam-Webster: America's Most-Trusted Online Dictionary, n.d.). In this case, Corpus of Contemporary American English (COCA) became the primary source of data, and The Oxford Dictionary Online \& The Merriam-Webster Dictionary Online became the secondary data to support the data from COCA. Additionally, the dictionaries were used for bring the literal meaning into the discussions.

In order to use another corpus data, this study preferred using COCA based on some considerations. Firstly, COCA is the largest English corpus that contains amount of data in different genres such as spoken language, academic writing, newspapers, fiction, magazines, and etc. However it contains million corpus data, it is free and accessible by every people. Besides, the corpus data are updated regularly in order that it suits as a main source of data, especially for studying the current use of English words in many genres.

Furthermore, the data are analyzed in two ways, namely analyzing the words by using componential analysis, and analyzing the collocation that exists between lexicons. In the first step, this study used componential analysis to find out the meaning and the distinctive meaning between words. Moreover, the meaning of words from The Oxford Dictionary Online and The Merriam-Webster Dictionary Online will be analyzed by concerning the distinctive feature of words.

After that, to make the deep analysis of words this study compiles it with collocation analysis in COCA. In this case, the semantic prosody will be seen in lexical index and lexical profiles which are in corpus linguistics. In exploring the corpus, the investigation will focus on identifying semantic collocations and preferences that are usually accessed through word profiles or concordance. According to Hoey (Stewart, 2009), collocation is a term used to describe the relationship between a lexical part and parts that appear regularly in a textual context. In other words, Firth (Stewart, 2009) implied that collocation is basically quantitative, entailing statistical significance and not only a juxtaposition. After that, the data can be analyzed at the level of semantic prosody. Finally, the results and discussions will be presented in a combination of simple statistics, tables, collocation data, and qualitative descriptions. 


\section{FINDINGS AND DISCUSSION}

\section{Findings}

Based on searches in the Merriam-Webster and Oxford dictionaries, it was found that the meaning of talkative, loquacious, chatty, gossipy, garrulous, conversational, and talky lexicon can be seen in the table below.

Table 1.The Meaning of Lexicons 'Talking a lot'

\begin{tabular}{|c|c|c|}
\hline Words & $\begin{array}{l}\text { Meaning } \\
\text { Webster) }\end{array}$ & Meaning 2 (Oxford) \\
\hline Talkative & $\begin{array}{l}\text { tending to talk a lot or to } \\
\text { enjoy having conversations } \\
\text { with people }\end{array}$ & Fond of or given to talking. \\
\hline Loquacious & $\begin{array}{l}\text { liking to talk and talking } \\
\text { smoothly and easily }\end{array}$ & $\begin{array}{l}\text { Tending to talk a great deal } \\
\text { talkative. }\end{array}$ \\
\hline Chatty & $\begin{array}{l}\text { tending to talk a lot; } \\
\text { fond of chatting, having an } \\
\text { informal style that is similar } \\
\text { to friendly speech }\end{array}$ & $\begin{array}{l}\text { Readily engaging in informal } \\
\text { talk; (of a conversation, letter, } \\
\text { etc.) informal and lively. }\end{array}$ \\
\hline Gossipy & $\begin{array}{l}\text { characterized by, full of, or } \\
\text { given to gossip }\end{array}$ & $\begin{array}{l}\text { Characterized by casual } \\
\text { conversation or reports about } \\
\text { other people; derogatory } \\
\text { Enjoying talking about other } \\
\text { people's private lives }\end{array}$ \\
\hline Garrulous & $\begin{array}{lcc}\text { fond of talking } & \text { or } \\
\text { conversation } & \text { pointlessly } & \text { or } \\
\text { annoyingly talkative } & \\
\end{array}$ & $\begin{array}{l}\text { Excessively talkative, especially } \\
\text { on trivial matters }\end{array}$ \\
\hline Conversational & $\begin{array}{l}\text { tending to do informal talk } \\
\text { involving two people or a } \\
\text { small group of people }\end{array}$ & $\begin{array}{l}\text { As used in conversation not } \\
\text { formal; Consisting of or relating } \\
\text { to conversation. }\end{array}$ \\
\hline Talky & $\begin{array}{l}\text { tending or wanting to talk } \\
\text { having a lot of talking }\end{array}$ & $\begin{array}{l}\text { (of a film, play, novel, etc.) } \\
\text { containing a great deal of talk or } \\
\text { dialogue; (of a person) inclined } \\
\text { to talk at length; talkative }\end{array}$ \\
\hline
\end{tabular}

From the data collections, it was found that the characteristics of shared meaning components in the lexicon of talkative, loquacious, chatty, gossipy, garrulous, conversational, talky, were [+SUBJECT ANIMATE] [+SUBJECT SINGLE-PLURAL] [ANIMATE-INANIMATE OBJECT] [SINGLE-PLURAL OBJECT] [ONE WAY COMMUNICATION]. In other side, some distinctive features that distinguish the near-synonym words that mean ' talking a lot', were in 
terms of the subject (actor), object (patient), type of communication, and the type of information involved, and causes of communication as shown in the appendix 1.

\section{Discussion}

\section{Semantic Prosody}

To determine the semantic prosody of the lexicon such as talkative, loquacious, chatty, gossipy, garrulous, conversational, talky, the data are analyzed by looking at the collocation around the lexicon. As Louw (Stewart, 2009) stated that a semantic prosody is established through some familiar themes such as the consistency of semantic collocation, and the attitudinal function of semantic prosody. In other words, a semantic prosody appears as the result of the relationship between the word and the collocates. In this case, three types of prosody were found in this study, namely positive prosody, negative prosody, and neutral prosody.

a. Positive Prosody (Amelioration)

Positive prosody as the meaning that generated in speech which is positive or as same as its expected (Prihantoro, 2015). In this case the lexicon that has a positive sense or prosody among others is talkative, loquacious, chatty, and talky.

In the COCA corpus, the word talkative is widely used in fiction and newspapers genre rather than in oral, magazine, and academic genre. Furthermore, by considering its significant collocates, it can be grouped into a number of forms, for instance, those which is related to gender (lady), and manner means (friendly, lively, cooperative, cheerful, energetic, relaxed). Consequently, it shows that talkative is relate to woman more than to man. 


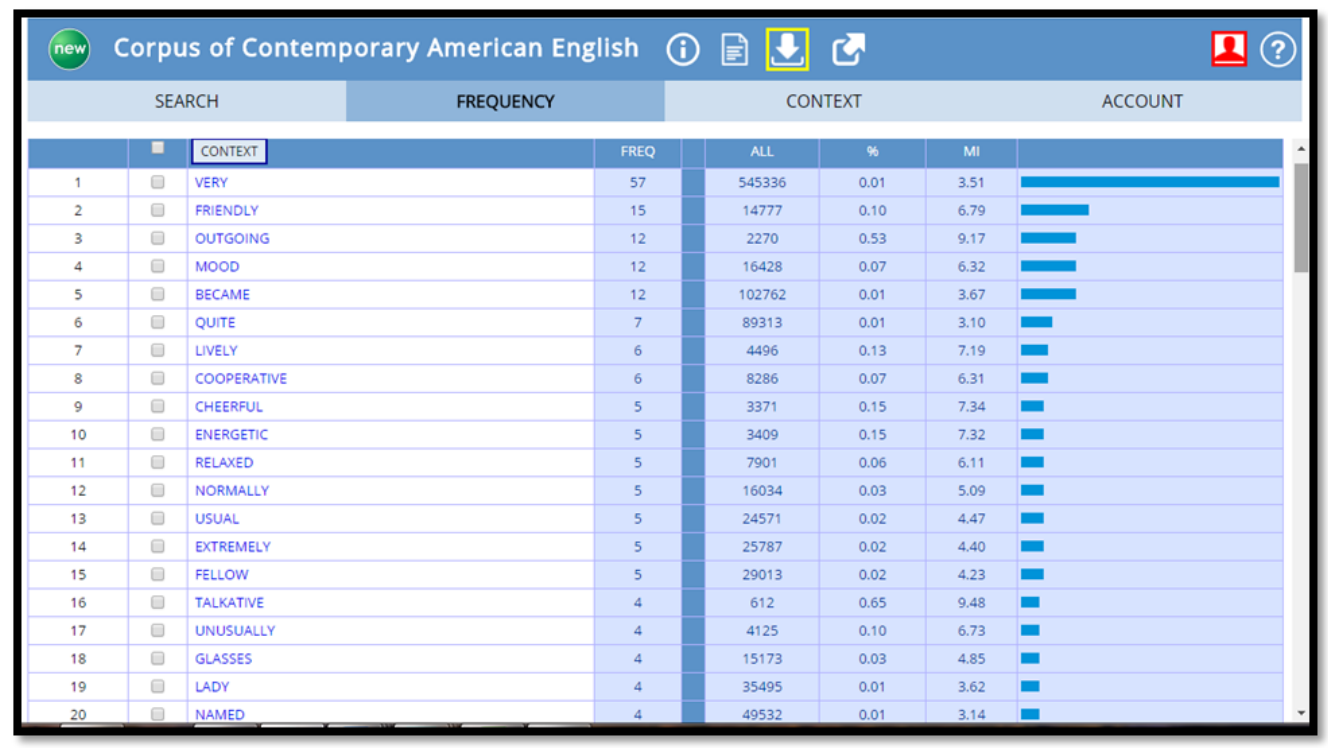

Figure 1. General Collocates of talkative

On the other hand, the data about top twenty collocates of talkative shows that it collocates with some adjectives such as friendly, outgoing, cooperative, lively, energetic, and cheerful. The collocation in this lexicon shows that the collocations are positive in extreme, because it does not collaborate with negative meaningful adjectives. As a result, talkative can be categorized as in positive prosody (amelioration).

The same thing is also seen in loquacious, which is more widely used in the genre of magazines and newspapers than in spoken, fiction, and academic genre. The general collocates of Loquacious can be seen on the table below.

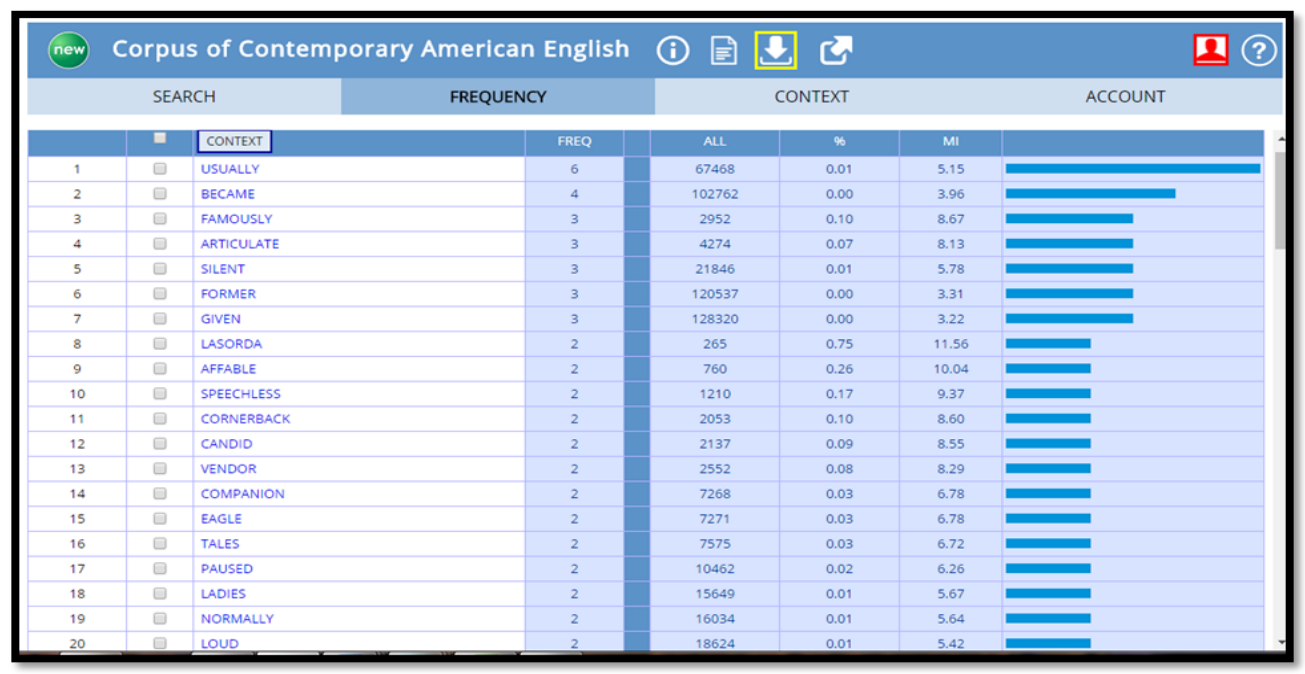

Figure 2. General Collocates of Loquacious 
In addition, by considering the general collocates above, collocates can be grouped into several groups such as, words related to gender (i.e ladies), words related to speech (i.e articulate, silent, affable, speechless, candid, pause, normally, loud), and words related to communication objects (i.e vendor, companion). In order that, it shows that loquacious is an adjective which relates to woman than man. Furthermore, it usually speaks of something in real with normal articulation and occurs in two way communication.

Specifically, loquacious looks more collocating with other adjectives, such as articulate, candid, affable, silent, and speechless. In order that, there is not negative meaningful words are found around this lexicon.

As well as talkative and loquacious, chatty is also categorized in positive prosody. It usually used in fiction and newsletters genre, compared to spoken, magazines, and academic genre. Then, the general collocates of chatty can be seen on the table below.

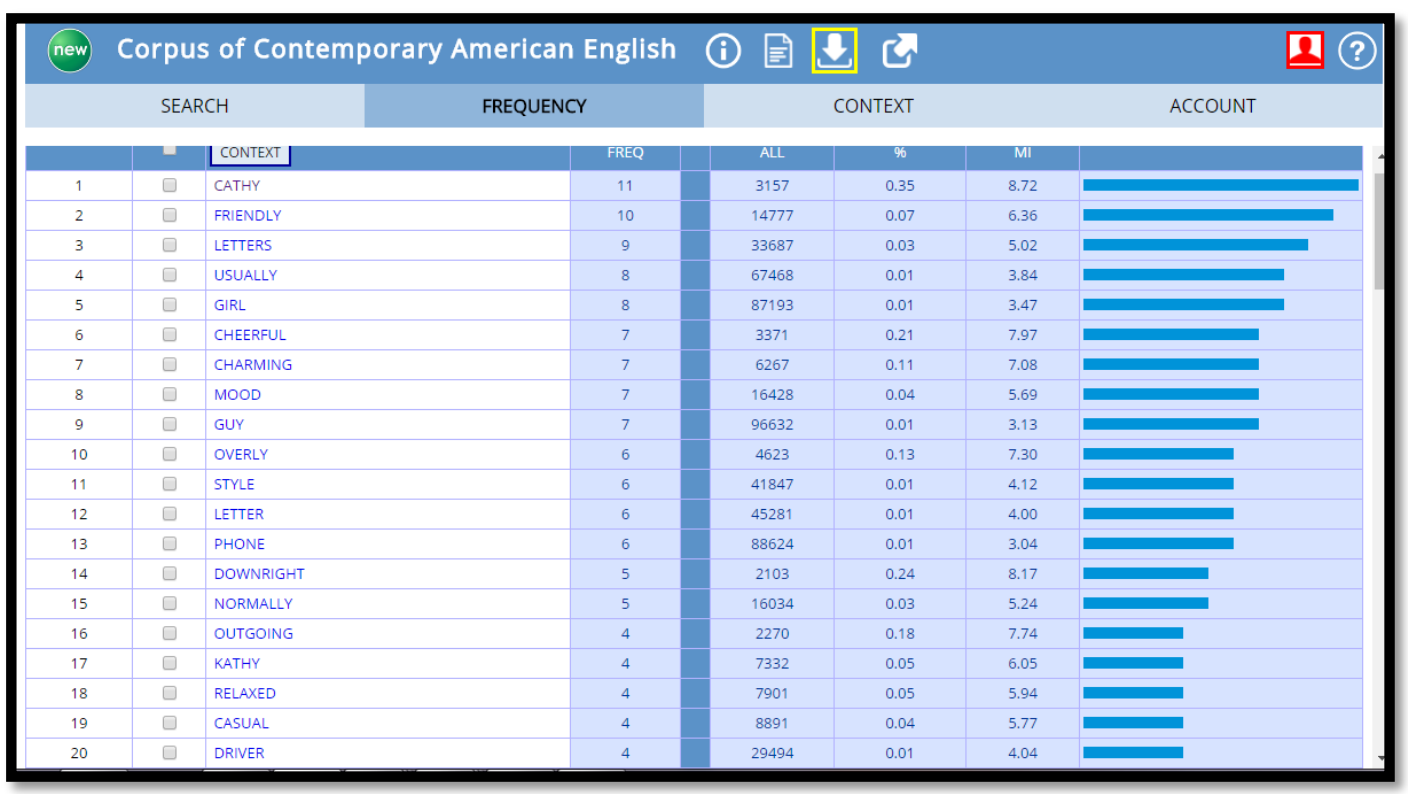

Figure 3. General Collocation of Chatty

Furthermore, by considering the general collocates above, collocates can be grouped into several groups such as, words related to the subject (i.e. girl, guy, driver, letters, phone), words related to speech (i.e. friendly, normally, outgoing, relaxed, casual), and words related to the object of conversation (i.e. mood, style). Based on this classification, it shows that chatty is not only related to women, but also men. The 
meaning of the speech in this adjective is a simple and familiar style of speech. In order, the conversation is becoming relaxed.

Specifically, lexicon chatty more collocating with other adjectives such as, friendly, cheerful, charming, casual, downright, outgoing. As a result, it categorized in positive prosody because it is surrounded by positive meaningful adjectives.

Finally, another lexicon that has a positive prosody is talky. This lexicon is more widely used in magazines and fiction genre than in spoken language, letter, and academic genre. The general collocates of talky can be seen on the table below.

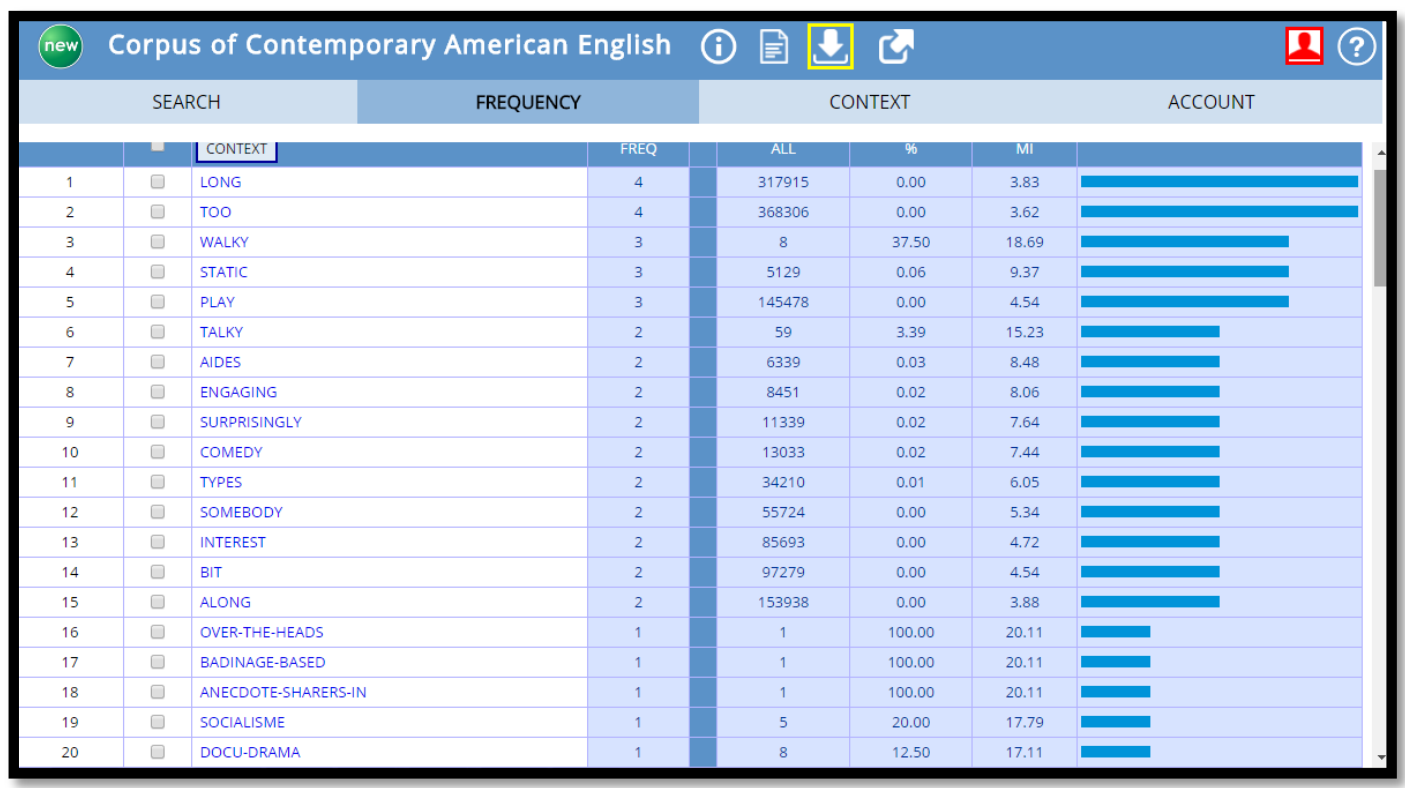

\section{Figure 4. General Collocation of Talky}

Moreover, by considering the general collocates of talky, they can be grouped in words related to purpose (i.e. play, socialism), words related to the way (i.e. long, static, engaging, surprisingly, along, badinage-based), words related to object form (i.e. comedy, over the heads, anecdote-shares-in, docudrama), and words related to the subject (i.e. somebody, aides). In order that, talky emphasizes the features speaking method used rather than the gender preferences of subject. Then, it usually relates to the objects of comedy, anecdotes and drama.

Additionally, the adjectives collocations of talky are only static, long, engaging, talky, walky. Moreover the adjectives only contained positive meanings. Therefore, talky is categorized as a positive prosody lexicon. 
b. Neutral Prosody

Prihantoro (2015) states that the neutral prosody is an aura meaning which is neutral generated. Based on the data, it was found that some lexicon 'talking a lot' which has neutral prosody are garrulous and conversational.

Firstly, garrulous is more used in fiction and magazine genre than in other genres. The general collocates of garrulous can be seen on the table below.

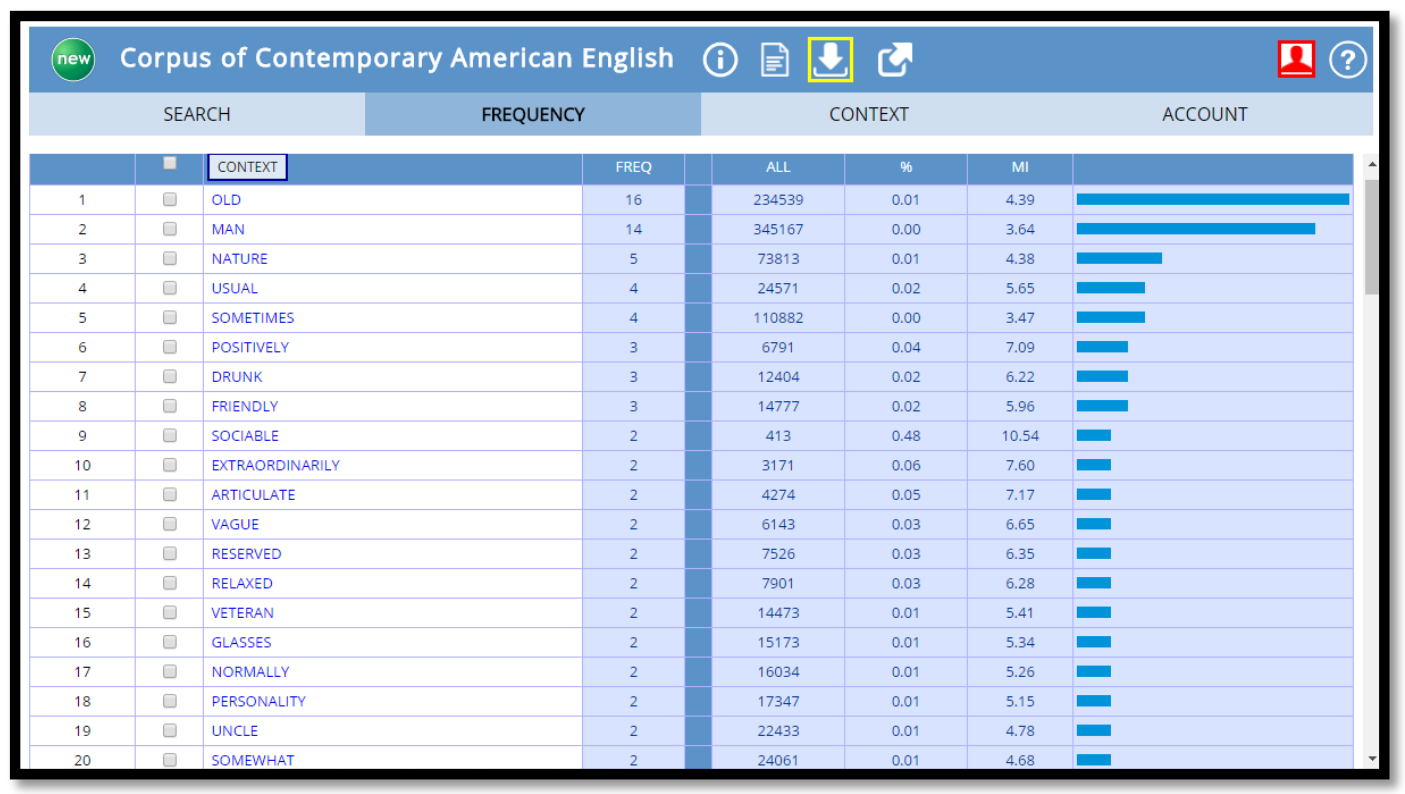

Figure 5. General Collocates of Garrulous

As a result of considering the general collocates of garrulous, they can be grouped into several groups such as words related to the cause of the conversation (i.e. nature, drunk, personality), words related to the subject conversation (i.e. old, man, veteran, uncle), words related to speech (i.e. articulate, positively, vague, relaxed, sociable, friendly), and words related to the frequency of events (i.e. usual, normally, extraordinarily).In order that, it shows that garrulous is mostly done by older men than women. Usually this trait arises purely because of the personality of the object.

However, specifically the adjectives around garrulous are usual, friendly, relaxed, old, drunk. On the other hand, there are three adjectives in positive meaning, namely usual, friendly, and relaxed. Meanwhile old, drunk, are considered in negative meaning. In order that, garrulous can be a flexible lexicon because it can be positive or negative. Therefore, this lexicon is categorized as a neutral prosody lexicon. 


\begin{tabular}{|c|c|c|c|c|c|c|c|}
\hline & \multicolumn{2}{|c|}{ SEARCH } & FREQUENCY & \multicolumn{2}{|c|}{ CONTEXT } & \multicolumn{2}{|r|}{ ACCOUNT } \\
\hline & 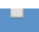 & CONTEXT & FREQ & AlL & $\%$ & MI & \\
\hline 1 & $\square$ & TONE & 75 & 20539 & 0.37 & 7.48 & - \\
\hline 2 & $\square$ & SAMPLES & 58 & 17074 & 0.34 & 7.38 & 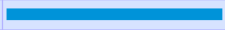 \\
\hline 3 & $\square$ & SPEECH & 55 & 44908 & 0.12 & 5.91 & - \\
\hline 4 & $\square$ & STYLE & 45 & 41847 & 0.11 & 5.72 & 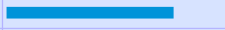 \\
\hline 5 & $\square$ & LANGUAGE & 37 & 73408 & 0.05 & 4.63 & 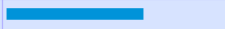 \\
\hline 6 & $\square$ & EXCHANGE & 34 & 29798 & 0.11 & 5.81 & - \\
\hline 7 & $\square$ & NARRATIVE & 32 & 18739 & 0.17 & 6.39 & $=$ \\
\hline 8 & $\square$ & SKILLS & 32 & 58794 & 0.05 & 4.74 & - \\
\hline 9 & $\square$ & VOICE & 32 & 105182 & 0.03 & 3.90 & 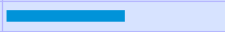 \\
\hline 10 & $\square$ & SAMPLE & 27 & 33787 & 0.08 & 5.29 & 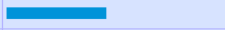 \\
\hline 11 & $\square$ & INTERACTION & 23 & 16137 & 0.14 & 6.13 & 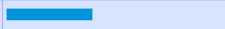 \\
\hline 12 & $\square$ & PARTNERS & 23 & 20774 & 0.11 & 5.76 & 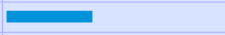 \\
\hline 13 & $\square$ & INTERVIEW & 23 & 44713 & 0.05 & 4.66 & 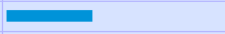 \\
\hline 14 & $\square$ & ENGLISH & 22 & 55827 & 0.04 & 4.27 & 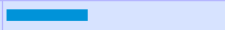 \\
\hline 15 & $\square$ & TOPICS & 16 & 11589 & 0.14 & 6.08 & $\square$ \\
\hline 16 & $\square$ & SPANISH & 14 & 22378 & 0.06 & 4.94 & $\square$ \\
\hline 17 & $\square$ & EXCHANGES & 13 & 4686 & 0.28 & 7.09 & $\square$ \\
\hline 18 & $\square$ & TASK & 12 & 39035 & 0.03 & 3.91 & $\square$ \\
\hline 19 & $\square$ & GAMBITS & 11 & 67 & 16.42 & 12.97 & - \\
\hline 20 & $\square$ & INTERFACE & 11 & 4811 & 0.23 & 6.81 & $\infty$ \\
\hline
\end{tabular}

Figure 6. General Collocates of Conversational

As well as garrulous, conversational is also categorized in neutral prosody. This lexicon is more widely used in the academic magazines genre rather than others. This lexicon is surrounded by its significant collocates that can be grouped into words related to speech features (i.e. tone, speech, style, language, skills, voice, topic), words related to speech forms (i.e. narrative, samples, interaction, interview, task, gambits), words related to place (i.e. interface), and words related to language (i.e. English, Spanish). In order that, conversational emphasizes the speaking features used rather than the gender preferences. Then, the general collocates of conversational can be seen on the table below.

In addition, the surrounded adjectives of conversational are English, Spanish. In order that, conversational lexicon tends to be neutral in nature because it is surrounded by adjectives that are neither positive nor negative. Hence, it cannot be in positive or negative prosody adjectives, but rather in neutral. 
c. Negative Prosody (Pejoration)

Negative Prosody refers to an aura of lexicon which has negative meaning or not as expected. In this study, it was found that there is only one lexicon that has negative prosody, namely gossipy. Gossipy is used more in fiction and magazine genre than other genre. As a result of considering the general collocates of gossipy, they can be grouped into words related to place (i.e. magazine, lunches, book, account, industry), words related to the form of conversation (i.e. conversation, written, writing), words related to subject of conversation (i.e. seller, neighbor), and words related to negative issues (i.e. tidbits, fussy, notoriously, superficial, erotic, weakness). In order that, it shows that gossipy is mostly done in the neighborhood and sellers. In this lexicon, gender preference is not dominant. Furthermore, the speech form is not only in oral form, but also in written form. Moreover, the content of this talk is usually negative issue based on the general collocations.

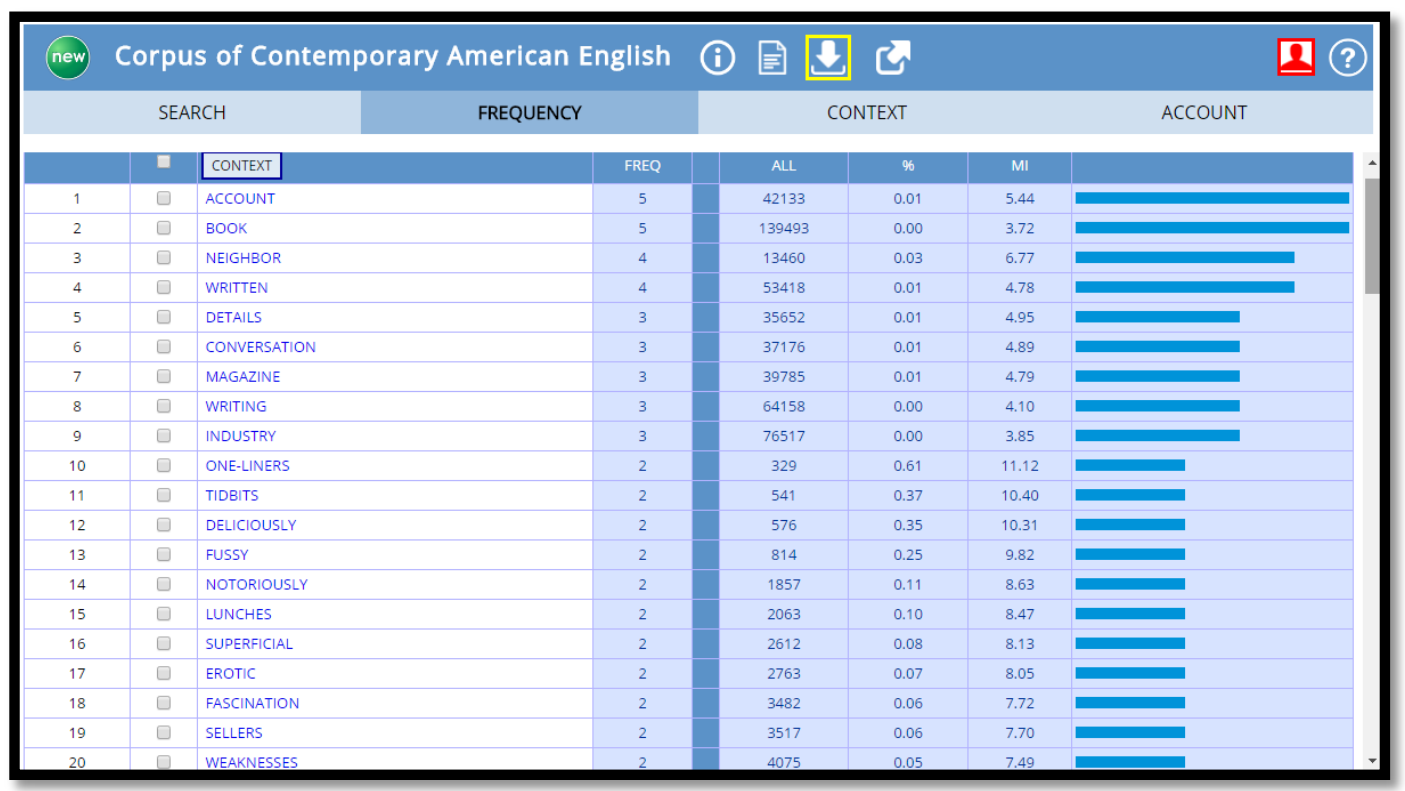

Figure 7. General Collocates of Gossipy

However, gossipy categorized in negative prosody as a result of the negative adjective collocations around it. In addition, the adjectives are superficial, erotic, and fussy.

\section{The Implications of Semantic Prosodies through Translation Practices}

Talking about the aura of near-synonym or words semantic prosody is always related to translation studies and practices. In this case, the implication of semantic prosody can be seen in the use of corpus-based approach in translation practice. It can 
be used in world level translation and also above word level translation. Corpus-based approach in translation is usually not only used for investigating the difference between the source language text and target language text, but how genres affect the translation work (Zanettin, 2014).

As well as above, the semantic prosody's implication through translation practice also shows in the analysis of semantic prosody in near-synonym 'talking a lot' words. In this talk, the collocations of words can show some systematic features of words. Furthermore, the aura or connotative meaning of near-synonym words obtained by corpus-based approach is indirectly showed that the corpus-based approach can be used well as an option in translation practice.

Therefore, the translators cannot only transfer word per word meanings, but also the values and cultures within the words. Due to above, the corpus-based approach is not only able to detect and analyze the systematic features of translation, but also can identify and provide the appropriate tools to test norms and regularities hypotheses in translated texts (Zanettin, 2014). The example of corpus-based approach in translating practice 'talking a lot' word can be seen on the table below.

Table 2. Example of gossipy corpus-based translation

\begin{tabular}{lllll}
\hline Word & \multicolumn{4}{c}{ Collocation } \\
\cline { 2 - 5 } & Related to place & $\begin{array}{c}\text { Related to } \\
\text { conversation } \\
\text { form }\end{array}$ & $\begin{array}{c}\text { Related to } \\
\text { conversation } \\
\text { subject }\end{array}$ & $\begin{array}{c}\text { Related to } \\
\text { negative } \\
\text { issues }\end{array}$ \\
\hline Gossipy & $\begin{array}{l}\text { magazine, } \\
\text { lunches, book, }\end{array}$ & $\begin{array}{l}\text { conversation, } \\
\text { written, }\end{array}$ & $\begin{array}{l}\text { seller, } \\
\text { neighbor }\end{array}$ & $\begin{array}{l}\text { tidbits, fussy, } \\
\text { notoriously, } \\
\text { superficial, } \\
\text { erotic, } \\
\text { writing }\end{array}$ \\
& & & & weakness \\
\hline
\end{tabular}

The word gossipy above is not only translated as a casual conversation, but it transfers some values and auras of word such as its genre, form, subject, and negative values. In order that, gossipy can be translated as a casual conversation which is used more in magazine genre than other genre. It has usually done by the neighbor and sellers, meanwhile the content always relates to negative issue.

Along with the discussion of semantic prosody implication through translation practice was emerged, the corpus methodology in translation practice was first introduced by Baker in 1993 (Baker, 2018). Baker suggested that translation study and 
practice can be done well by elucidating translated text through its construction, in order that the observations can be done through the relative frequencies of specific words, word classes, collocations and lexico-syntactic structures (Malmkjær, 2018). However, the translation approach is not basically well-developed in Indonesia translation practice. This is because it requires more technologies in translating text, such as some corpus data (COCA, BNC, COHA, GloWbE), Computer-Assisted Rranslation software, AntConc, Sketch Engine, and etc. In addition, the corpus-based approach is generally mastered by advanced translators more than by beginner translators. Hence, corpusbased approach is very feasible to use in Indonesia translation studies and practice. For this reason, it is useful to facilitate foreign language learner and foreign language translator in comprehending new words. Identically, corpus-based approach can improve the quality of translation work, especially the accuracy level in meaning transference.

\section{CONCLUSIONS}

To sum up, all near-synonym adjectives which mean 'talking a lot' are not in perfect synonym. They have to be used agree with the context. Based on the research above, it can be concluded that the distinctive features of the adjectives mean 'talking a lot' are subjects, objects, types of communication, types of information, and causes of communication. Besides, some lexicon such as talkative, loquacious, chatty, and talky are categorized as lexicon which have positive prosody in extreme. Moreover, garrulous and conversational are neutral, because they can be positive or negative depending on the context. On the other hand, gossipy is the only lexicon that tends to have negative prosody. Hence, the words semantic prosody is always related to translation studies and practices through corpus-based approach. It facilitates foreign language learner and foreign language translator in comprehending new words, and improves the quality of translation work. 


\section{REFERENCES}

Baker, M. (2018). In other words:A coursebook on translatoin. In Development (Vol. 134, Issue 4). Routledge.

Biber, D., \& Reppen, R. (2015). The Cambridge handbook of English corpus linguistics. In The Cambridge Handbook of English Corpus Linguistics. https://doi.org/10.1007/9781139764377

Charles, M. (2011). The Routledge Handbook of Corpus Linguistics. System. https://doi.org/10.1016/j.system.2011.01.004

Corpus of Contemporary American-English (COCA). (n.d.). http://corpus.byu.edu/coca/

Definitions, Meanings, Synonyms, and Grammar by Oxford Dictionary on Lexico.com. (n.d.). $\quad$ Retrieved May 2, 2020, from https://www.lexico.com/?search_filter=en_dictionary

Dictionary by Merriam-Webster: America's most-trusted online dictionary. (n.d.). Retrieved May 3, 2020, from https://www.merriam-webster.com/

Liu, D. (2010). Is it a chief , main , major , primary , or principal concern?: A corpusbased behavioral profile study of the near-synonyms . International Journal of Corpus Linguistics, 15(1), 56-87. https://doi.org/10.1075/ijcl.15.1.03liu

Malmkjær, K. (2018). The Routledge Handbook of Translation Studies and Linguistics. In The Routledge Handbook of Translation Studies and Linguistics. Routledge. https://doi.org/10.4324/9781315692845

McEnery, T., \& Hardie, A. (2011). Corpus linguistics: Method, theory and practice. In Corpus Linguistics: Method, Theory and Practice. https://doi.org/10.1017/CBO9780511981395

McEnery, T., \& Wilson, A. (2001). 7. Corpus linguistics: An introduction. Corpus Linguistics: An Introduction.

Nugroho, D. Y. (2018). A Corpus Linguistics Investigation Of Two Near-Synonymous Words: Rich and Wealthy. English Education: Journal of English Teaching and Research, 3(2), 118-127. https://doi.org/10.29407/JETAR.V3I2.12568

OKeeffe, A., McCarthy, M., \& Carter, R. (2007). From Corpus to Classroom. In From Corpus to Classroom. https://doi.org/10.1017/cbo9780511497650

Partington, A. (2004). "Utterly content in each other's company": Semantic prosody and semantic preference. International Journal of Corpus Linguistics. https://doi.org/10.1075/ijcl.9.1.07par

Potter, S., \& Ullmann, S. (1963). Semantics. An Introduction to the Science of Meaning. The Modern Language Review. https://doi.org/10.2307/3720401 
Prihantoro. (2015). Semantic prosody of words of effects in Indonesian. Indonesian Journal of Applied Linguistics. https://doi.org/10.17509/ijal.v5i1.837

Stewart, D. (2009). Semantic prosody: A critical evaluation. In Semantic Prosody: A Critical Evaluation. https://doi.org/10.4324/9780203870075

Stubbs, M. (2001). Words and Phrases: Corpus Studies of Lexical Semantics.

Tijjani Zahradeen, N. (2020). Componential Analysis od English "Crying" Terms. In International Journal of Advanced Academic Research | Arts, Humanities and Education| (Vol. 6, Issue 2).

Treechayawong, A., Tangkiengsirisin, S., Intamano, B., Sappapan, P., Kaewchum, C., Suriyatham, W., Ongsara, F., Rimkeeratikul, S., Da, H., Koowuttayakorn, S., Hwungsookkasem, J., Sompong, M., Jongjit, J., Sitthikul, P., Daji, K., Sappapan, P., Wongrat, K., Simasangyaporn, N., Jullanan, K., ... Aiyarakarnajanakul, W. (2019). Board of 8 th LITU International Graduate Conference Proceedings (P. Sappapan \& S. Koowuttayakorn (Eds.); pp. 5-605). Language Institure Thammasat University.

Xiao, R., \& McEnery, T. (2006). Collocation, semantic prosody, and near synonymy: A cross-linguistic perspective. Applied Linguistics. https://doi.org/10.1093/applin/ami045

Yuliawati, S. (2016). Profil Semantis Nomina Perempuan dalam Korpus Majalah Berbahasa Sunda (Mangle, 1958-2013). In Kongres Internasional Masyarakat Linguistik Indonesia.

Zanettin, F. (2014). Corpora in Translator Education. In Corpora in Translator Education. https://doi.org/10.4324/9781315760162. 
Appendix. Componential Analysis and Distinctive Features Table

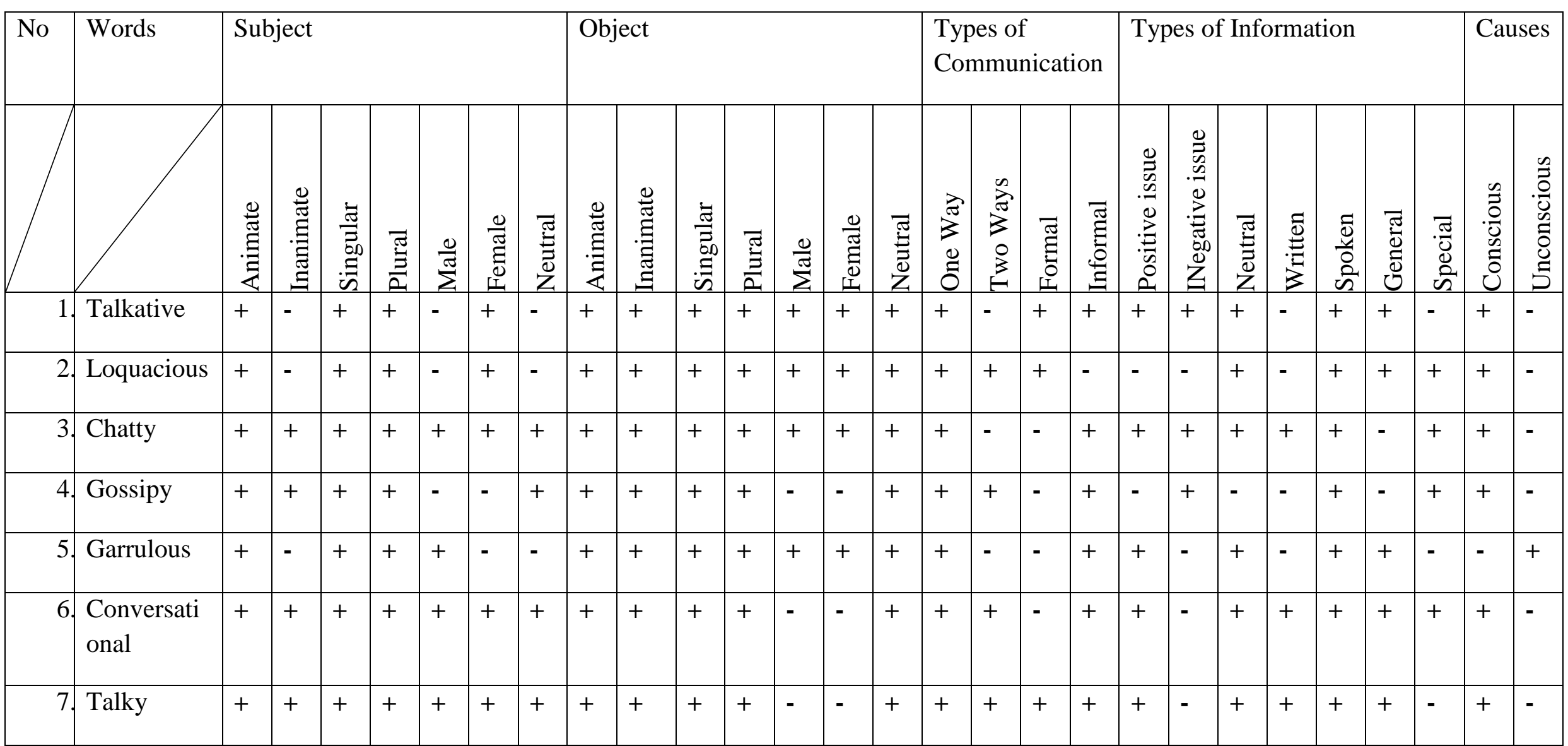

